\title{
PENERAPAN METODE K-NEAREST NEIGHBOR DAN INFORMATION GAIN PADA KLASIFIKASI KINERJA SISWA
}

\author{
Tyas Setiyorini1; Rizky Tri Asmono² \\ Teknik Informatika ${ }^{1}$ \\ STMIK Nusa Mandiri Jakarta ${ }^{1}$; \\ http://nusamandiri.ac.id ${ }^{1}$ \\ tyas.setiyorini@gmail.com ${ }^{1}$ \\ Teknik Informatika ${ }^{2}$ \\ STMIK Swadharma ${ }^{2}$ \\ http://swadharma.ac.id ${ }^{2}$ \\ rtriasmono@gmail.com²
}

\begin{abstract}
Education is a very important problem in the development of a country. One way to reach the level of quality of education is to predict student academic performance. The method used is still using an ineffective way because evaluation is based solely on the educator's assessment of information on the progress of student learning. Information on the progress of student learning is not enough to form indicators in evaluating student performance and helping students and educators to make improvements in learning and teaching. K-Nearest Neighbor is an effective method for classifying student performance, but K-Nearest Neighbor has problems in terms of large vector dimensions. To solve this problem, the Information Gain feature selection method is needed to reduce vector dimensions. Several experiments were conducted to obtain an optimal architecture and produce accurate classifications. The results of 10 experiments with a value of $k$ (1 to 10) on the student performance dataset using the K-Nearest Neighbor method showed the highest average accuracy of 74.068 whereas the K-Nearest Neighbor and Information Gain methods obtained the highest average accuracy of 76.553. From the results of these tests it can be concluded that Information Gain is able to reduce the vector dimensions, so that the application of K-Nearest Neighbor and Information Gain can improve the accuracy of student performance classification better than using the K-Nearest Neighbor method.
\end{abstract}

Keywords: K-Nearest Neighbor, Information Gain, Student Performance

Intisari- Pendidikan merupakan masalah yang sangat penting dalam perkembangan suatu negara. Salah satu cara untuk mencapai tingkat kualitas pendidikan adalah dengan memprediksi kinerja akademik siswa. Metode yang dilakukan masih menggunakan cara yang tidak efektif karena evaluasi hanya berdasarkan pada penilaian pendidik terhadap informasi kemajuan pembelajaran siswa. Informasi kemajuan pembelajaran siswa tidak cukup untuk membentuk indikator dalam mengevaluasi kinerja siswa serta membantu para siswa dan pendidik untuk melakukan perbaikan dalam pembelajaran dan pengajaran. K-Nearest Neighbor merupakan metode yang efektif untuk klasifikasi kinerja siswa, namun K-Nearest Neighbor memiliki masalah dalam hal dimensi vektor yang besar. Untuk menyelesaikan masalah tersebut diperlukan metode seleksi fitur Information Gain untuk mengurangi dimensi vektor. Beberapa percobaan dilakukan untuk mendapatkan arsitektur yang optimal dan menghasilkan klasifikasi yang akurat. Hasil dari 10 percobaan dengan nilai k (1 sampai dengan 10) pada dataset student performance dengan metode K-Nearest Neighbor didapatkan rata-rata akurasi terbesar yaitu 74,068 sedangkan dengan metode K-Nearest Neighbor dan Information Gain didapatkan rata-rata akurasi terbesar yaitu 76,553. Dari hasil pengujian tersebut maka dapat disimpulkan bahwa Information Gain mampu mengurangi dimensi vektor, sehingga penerapan K-Nearest Neighbor dan Information Gain dapat meningkatkan akurasi klasifikasi kinerja siswa yang lebih baik dibanding dengan menggunakan metode K-Nearest Neighbor saja. .

Kata Kunci: K-Nearest Neighbor, Information Gain, Kinerja Siswa

\section{PENDAHULUAN}

Pendidikan merupakan masalah yang sangat penting dalam perkembangan suatu negara. Pendidikan yang berkualitas merupakan tujuan 
utama dalam sebuah lembaga pendidikan. Salah satu cara untuk mencapai tingkat kualitas pendidikan adalah dengan memprediksi kinerja akademik siswa (Hamsa, Indiradevi, \& Kizhakkethottam, 2016). Memprediksi secara akurat kinerja akademik siswa pada tahap awal pembelajaran membantu dalam mengidentifikasi siswa yang lemah dan memungkinkan manajemen untuk mengambil tindakan korektif untuk mencegah mereka dari kegagalan (Pandey \& Taruna, 2016). Menyajikan pendidikan yang berkualitas dalam meningkatkan kinerja siswa merupakan tujuan utama dari lembaga pendidikan (Hamsa et al., 2016). Untuk mencapai tujuan tersebut, yang perlu dilakukan adalah menganalisis faktor-faktor apa saja yang mempengaruhi kinerja siswa. Dengan menganalisis kinerja siswa, program strategis dapat direncanakan dengan baik selama masa studi mereka di sebuah institusi (Ibrahim \& Rusli, 2007). Namun, pekerjaan yang ada tidak menyediakan alat analisis yang cukup untuk menganalisis bagaimana siswa melakukan, faktor mana yang akan mempengaruhi kinerjanya, dengan cara mana siswa dapat membuat kemajuan, dan apakah siswa memiliki potensi untuk melakukan yang lebih baik (Yang \& Li, 2018). Informasi kemajuan pembelajaran siswa menjadi salah satu faktor penilaian seorang pendidik dalam menganalisis kinerja siswa. Namun cara tersebut tidaklah efektif karena informasi kemajuan pembelajaran siswa tidak cukup sebagai indikator para siswa dan pendidik untuk melakukan perbaikan dalam pengajaran dan pembelajaran (Yang \& Li, 2018).

Salah satu teknik yang paling populer untuk menganalisis kinerja siswa adalah data mining (Shahiri, Husain, \& Rashid, 2015). Pendekatan data mining diusulkan untuk memprediksi kinerja siswa (Hamsa et al., 2016). Beberapa penelitian telah dilakukan dalam memprediksi kinerja siswa dengan teknik klasifikasi, seperti K-Nearest Neighbor (Pandey \& Taruna, 2016), Regression (Conijn, Snijders, Kleingeld, \& Matzat, 2017), Support Vector Machine (Al-Shehri et al., 2017), Decision Tree (Lopez Guarin, Guzman, \& Gonzalez, 2015), Naive Bayes (Lopez Guarin et al., 2015), dan Artificial Neural Networks (Alkhasawneh \& Hobson, 2011). K-Nearest Neighbor bersifat efektif, intuitif dan sederhana sehingga K-Nearest Neighbor telah menarik minat luas dalam komunitas penelitian (Gou et al., 2014)(Lin, Li, Lin, \& Chen, 2014)(Lin et al., 2014). K-Nearest Neighbor adalah salah satu metode yang mampu memecahkan masalah klasifikasi, sering menghasilkan hasil yang kompetitif dan memiliki keuntungan yang signifikan atas beberapa metode penambangan data lainnya (Adeniyi, Wei, \& Yongquan, 2016).

K-Nearest Neighbor merupakan metode yang efektif namun memiliki beberapa kekurangan yaitu kompleksitas komputasi kemiripan datanya besar, kinerjanya mudah dipengaruhi oleh data noise, K-Nearest Neighbor merupakan metode lazy learning sehingga tidak membangun model klasifikasi. Untuk mengurangi kompleksitas KNearest Neighbor dapat dilakukan dengan tiga metode umum, yaitu mengurangi jumlah data pelatihan (Lu \& Fa, 2004), mempercepat proses menemukan k tetangga terdekat (Aghbari, 2005), atau mengurangi dimensi vektor (de Vries, Mamoulis, Nes, \& Kersten, 2003).

Seleksi fitur (feature selection) dapat digunakan untuk mengurangi dimensi vektor pada dataset student performance. Seleksi fitur merupakan salah satu bagian terpenting dalam mengoptimalkan performa classifier (Wang, Li, Song, Wei, \& Li, 2011). Seleksi fitur berdasarkan pada pengurangan fitur yang besar, yaitu dengan menghapus atribut yang tidak relevan (Koncz \& Paralic, 2011). Menggunakan algoritma seleksi fitur yang tepat dapat meningkatkan akurasi (Xu, Peng, \& Cheng, 2012)(George Gorman, 2003).

Yang dan Perdersen (Vercellis, 2009) melakukan perbandingan 5 algoritma seleksi fitur pada klasifikasi. Lima algoritma tersebut antara lain mutual information, term strength, chi-square, Information Gain, dan document frequency. Hasil penelitian tersebut membuktikan bahwa chisquare dan Information Gain paling efisien. Tan dan Zang (Zhang \& Tan, 2008) menggunakan algoritma seleksi fitur yang menunjukkan Information Gain mendapatkan hasil yang paling baik. Hal tersebut menunjukkan bahwa Information Gain memiliki potensi yang lebih baik dalam proses menghilangkan fitur yang kurang relevan sehingga dapat mengurangi dimensi vektor sebelum dilakukannya klasifikasi. Untuk itu penelitian ini akan menggunakan kombinasi kedua metode yaitu K-Nearest Neighbor dan Information Gain untuk melakukan klasifikasi kinerja siswa sehingga mendapatkan tingkat akurasi yang optimal.

\section{BAHAN DAN METODE}

\section{Bahan}

Dataset student performance digunakan pada penelitian ini. Dataset tersebut didapat dari UCI Machine Learning Repository. Dataset student performance terdiri dari 30 atribut dan 1 kelas. Tabel 1 menunjukkan atribut dan keterangannya. Tabel 2 menunjukkan atribut, data, dan keterangan datanya. 
Tabel 1. Atribut dan Keterangan pada Dataset Student Performance

\begin{tabular}{|c|c|c|}
\hline No & Atribut & Keterangan \\
\hline 1 & Result & $\begin{array}{lr}\text { Hasil } & \text { kelulusan. } \\
\text { (Merupakan } & \text { atribut } \\
\text { class) } & \\
\end{array}$ \\
\hline 2 & School & Nama Sekolah \\
\hline 3 & Sex & Jenis Kelamin \\
\hline 4 & Age & Umur \\
\hline 5 & Address & Alamat \\
\hline 6 & Famsize & $\begin{array}{l}\text { Jumlah anggota } \\
\text { keluarga }\end{array}$ \\
\hline 7 & Pstatus & $\begin{array}{l}\text { Status tinggal dengan } \\
\text { orang tua atau tidak }\end{array}$ \\
\hline 8 & Medu & Pendidikan ibu \\
\hline 9 & Fedu & Pendidikan ayah \\
\hline 10 & Mjob & Pekerjaan ibu \\
\hline 11 & Fjob & Pekerjaan ayah \\
\hline 12 & Reason & Alasan memilih sekolah \\
\hline 13 & Guardian & Wali siswa \\
\hline 14 & Traveltime & $\begin{array}{l}\text { Waktu tempuh dari } \\
\text { rumah ke sekolah }\end{array}$ \\
\hline 15 & Studytime & $\begin{array}{l}\text { Waktu belajar dalam } \\
\text { seminggu }\end{array}$ \\
\hline 16 & Failures & Jumlah ketidaklulusan \\
\hline 17 & Schoolsup & $\begin{array}{l}\text { Dukungan pendidikan } \\
\text { tambahan }\end{array}$ \\
\hline 18 & Famsup & $\begin{array}{l}\text { Dukungan pendidikan } \\
\text { keluarga }\end{array}$ \\
\hline 19 & Paid & Les tambahan \\
\hline 20 & Activities & $\begin{array}{l}\text { Kegiatan } \\
\text { ekstrakurikuler }\end{array}$ \\
\hline 21 & Nursery & \\
\hline 22 & Higher & $\begin{array}{l}\text { Ingin mengambil } \\
\text { pendidikan tinggi }\end{array}$ \\
\hline 23 & Internet & $\begin{array}{l}\text { Akses internet di } \\
\text { rumah }\end{array}$ \\
\hline 24 & Romantic & $\begin{array}{l}\text { Mempunyai pacar atau } \\
\text { tidak }\end{array}$ \\
\hline 25 & Famrel & $\begin{array}{ll}\text { Kualitas } & \text { hubungan } \\
\text { keluarga } & \\
\end{array}$ \\
\hline 26 & Freetime & $\begin{array}{l}\text { Waktu luang setelah } \\
\text { sekolah }\end{array}$ \\
\hline 27 & Goout & $\begin{array}{l}\text { Pergi bersama teman- } \\
\text { teman }\end{array}$ \\
\hline 28 & Dalc & $\begin{array}{l}\text { Mengkonsumsi alkohol } \\
\text { pada hari kerja }\end{array}$ \\
\hline 29 & Walc & $\begin{array}{l}\text { Mengkonsumsi alkohol } \\
\text { pada akhir pekan }\end{array}$ \\
\hline 30 & Health & $\begin{array}{l}\text { Status kesehatan saat } \\
\text { ini }\end{array}$ \\
\hline 31 & Absences & Jumlah ketidakhadiran \\
\hline
\end{tabular}

Tabel 2. Atribut, Data dan Keterangan Data pada Dataset Student Performance

\begin{tabular}{|c|c|c|c|}
\hline No & Atribut & Data & $\begin{array}{l}\text { Keterangan } \\
\text { Data }\end{array}$ \\
\hline 1 & Result & Fail/pass & Gagal/ lulus \\
\hline \multirow[t]{2}{*}{2} & \multirow[t]{2}{*}{ School } & \multirow[t]{2}{*}{ MS/ GP } & $\begin{array}{l}\text { MS: } \\
\text { Mousinho da } \\
\text { Silveira }\end{array}$ \\
\hline & & & $\begin{array}{l}\text { GP: Gabriel } \\
\text { Pereira }\end{array}$ \\
\hline 3 & Sex & $\mathrm{M} / \mathrm{F}$ & $\begin{array}{l}\text { Laki-laki/ } \\
\text { perempuan }\end{array}$ \\
\hline 4 & Age & $15-22$ & \\
\hline 5 & Address & $\mathrm{R} / \mathrm{U}$ & $\begin{array}{l}\text { R: rural, U: } \\
\text { urban }\end{array}$ \\
\hline 6 & Famsize & LE3/GT3 & $\begin{array}{l}\text { LE3: }<=3 \\
\text { GT: }>3\end{array}$ \\
\hline 7 & Pstatus & $\mathrm{A} / \mathrm{T}$ & $\begin{array}{l}\text { A: terpisah } \\
\mathrm{T}: \text { bersama } \\
\text { orang tua }\end{array}$ \\
\hline 8 & Medu & $0 / 1 / 2 / 3 / 4$ & $\begin{array}{l}\text { 0: tidak ada } \\
\text { 1: SD } \\
\text { 2: SMP } \\
\text { 3: SMA } \\
\text { 4: } \\
\text { pendidikan } \\
\text { yang lebih } \\
\text { tinggi }\end{array}$ \\
\hline 9 & Fedu & $0 / 1 / 2 / 3 / 4$ & $\begin{array}{l}\text { 0: tidak ada } \\
\text { 1: SD } \\
\text { 2: SMP } \\
\text { 3: SMA } \\
\text { 4: } \\
\text { pendidikan } \\
\text { yang lebih } \\
\text { tinggi }\end{array}$ \\
\hline 10 & Mjob & $\begin{array}{l}\text { Techer/ } \\
\text { health/ } \\
\text { services/ at } \\
\text { home/ other }\end{array}$ & $\begin{array}{l}\text { Teacher: } \\
\text { guru } \\
\text { Health: di } \\
\text { bidang } \\
\text { kesehatan } \\
\text { Services: PNS } \\
\text { At home: di } \\
\text { rumah } \\
\text { Other: lain- } \\
\text { lain } \\
\end{array}$ \\
\hline 11 & Fjob & $\begin{array}{l}\text { Techer/ } \\
\text { health/ } \\
\text { services/ at } \\
\text { home/ other }\end{array}$ & $\begin{array}{l}\text { Teacher: } \\
\text { guru } \\
\text { Health: di } \\
\text { bidang } \\
\text { kesehatan } \\
\text { Services: PNS } \\
\text { At home: di } \\
\text { rumah }\end{array}$ \\
\hline
\end{tabular}




\begin{tabular}{|c|c|c|c|}
\hline & & & $\begin{array}{l}\text { Other: lain- } \\
\text { lain }\end{array}$ \\
\hline 12 & Reason & $\begin{array}{l}\text { Home/ } \\
\text { reputation/ } \\
\text { course/ } \\
\text { other }\end{array}$ & $\begin{array}{l}\text { Home: dekat } \\
\text { dengan } \\
\text { rumah } \\
\text { Reputation: } \\
\text { reputasi } \\
\text { sekolah } \\
\text { Course: mata } \\
\text { pelajaran }\end{array}$ \\
\hline 13 & Guardian & $\begin{array}{l}\text { Mother/ } \\
\text { father/ other }\end{array}$ & $\begin{array}{l}\text { Ayah/ Ibu/ } \\
\text { Lain-lain }\end{array}$ \\
\hline 14 & Traveltime & $1 / 2 / 3 / 4$ & $\begin{array}{l}1:<15 \text { menit } \\
2: \quad 15-30 \\
\text { menit } \\
3: 30 \text { menit- } \\
1 \text { jam } \\
4:>1 \text { jam }\end{array}$ \\
\hline 15 & Studytime & $1 / 2 / 3 / 4$ & $\begin{array}{l}1:<2 \text { jam } \\
2: 2-5 \text { jam } \\
3: 5-10 \text { jam } \\
\text { jam } \\
4:>10 \text { jam }\end{array}$ \\
\hline 16 & Failures & $1 / 2 / 3 / 4$ & $\begin{array}{l}\text { 1: } 1 \text { kali } \\
\text { 2: } 2 \text { kali } \\
\text { 3: } 3 \text { kali } \\
4:>3 \text { kali }\end{array}$ \\
\hline
\end{tabular}

\begin{tabular}{|c|c|c|c|}
\hline & & & baik \\
\hline \multirow[t]{2}{*}{28} & \multirow[t]{2}{*}{ Dalc } & \multirow[t]{2}{*}{$1 / 2 / 3 / 4 / 5$} & $\begin{array}{l}\text { 1: sangat } \\
\text { buruk } \\
\text { 2: buruk } \\
\text { 3: normal } \\
\text { 4: baik }\end{array}$ \\
\hline & & & $\begin{array}{l}5: \text { sangat } \\
\text { baik }\end{array}$ \\
\hline \multirow[t]{2}{*}{29} & \multirow[t]{2}{*}{ Walc } & \multirow[t]{2}{*}{$1 / 2 / 3 / 4 / 5$} & $\begin{array}{l}\text { 1: sangat } \\
\text { buruk } \\
\text { 2: buruk } \\
\text { 3: normal } \\
\text { 4: baik }\end{array}$ \\
\hline & & & $\begin{array}{l}5: \quad \text { sangat } \\
\text { baik }\end{array}$ \\
\hline \multirow[t]{2}{*}{30} & \multirow[t]{2}{*}{ Health } & \multirow[t]{2}{*}{$1 / 2 / 3 / 4 / 5$} & $\begin{array}{l}\text { 1: sangat } \\
\text { buruk } \\
\text { 2: buruk } \\
\text { 3: normal } \\
\text { 4: baik }\end{array}$ \\
\hline & & & $\begin{array}{l}\text { 5: } \quad \text { sangat } \\
\text { baik }\end{array}$ \\
\hline
\end{tabular}

\begin{tabular}{|c|c|c|c|}
\hline 17 & Schoolsup & Yes/no & \\
\hline 18 & Famsup & Yes/no & \\
\hline 19 & Paid & Yes/no & \\
\hline 20 & Activities & Yes/no & \\
\hline 21 & Nursery & Yes/no & \\
\hline 22 & Higher & Yes/no & \\
\hline 23 & Internet & Yes/no & \\
\hline 24 & Romantic & Yes/no & \\
\hline \multirow[t]{2}{*}{25} & Famrel & $1 / 2 / 3 / 4 / 5$ & $\begin{array}{l}\text { 1: sangat } \\
\text { buruk } \\
\text { 2: buruk } \\
\text { 3: normal } \\
\text { 4: baik }\end{array}$ \\
\hline & & & $\begin{array}{l}\text { 5: } \quad \text { sangat } \\
\text { baik }\end{array}$ \\
\hline \multirow[t]{2}{*}{26} & Freetime & $1 / 2 / 3 / 4 / 5$ & $\begin{array}{l}\text { 1: sangat } \\
\text { buruk } \\
\text { 2: buruk } \\
\text { 3: normal } \\
\text { 4: baik }\end{array}$ \\
\hline & & & $\begin{array}{l}5: \quad \text { sangat } \\
\text { baik }\end{array}$ \\
\hline \multirow[t]{2}{*}{27} & Goout & $1 / 2 / 3 / 4 / 5$ & $\begin{array}{l}\text { 1: sangat } \\
\text { buruk } \\
\text { 2: buruk } \\
\text { 3: normal } \\
\text { 4: baik }\end{array}$ \\
\hline & & & 5: sangat \\
\hline
\end{tabular}

31 Absences 0-75

Sumber: (Cortez \& Silva, 2008)

Metode

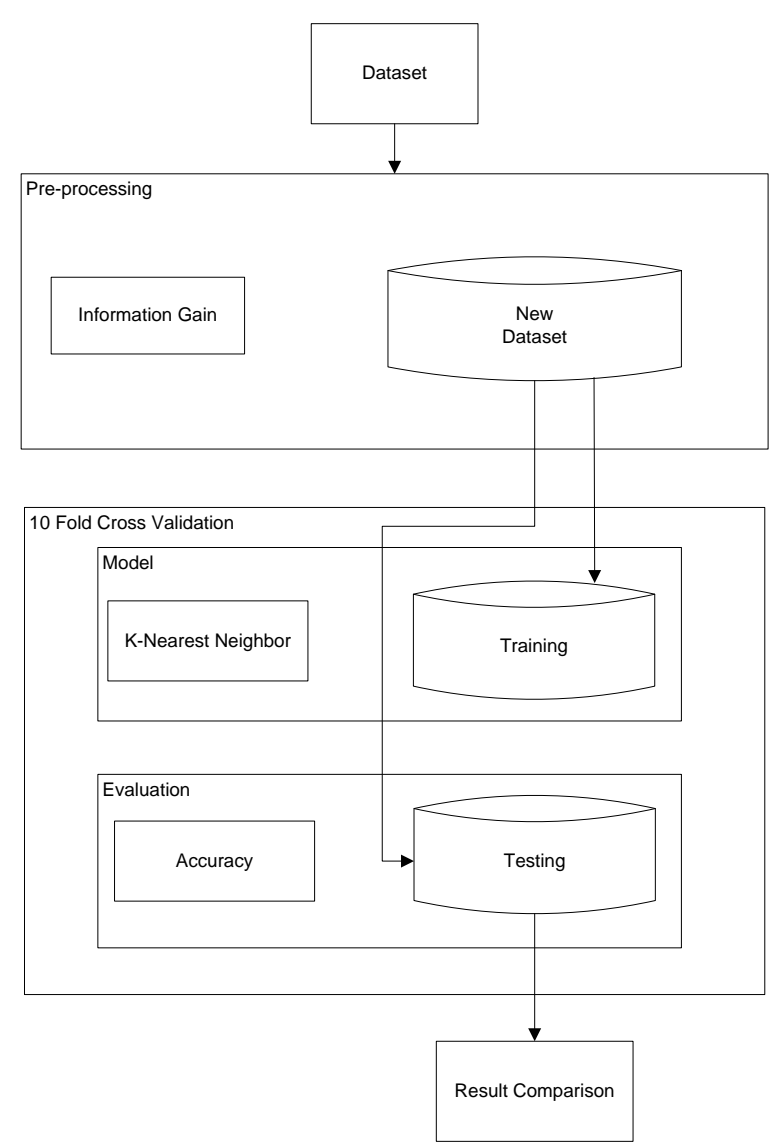

Sumber: (Setiyorini \& Asmono, 2019) 
Gambar 1. Penerapan Metode K-Nearest Neighbor dan Information Gain

Gambar 1 menggambarkan metode yang diusulkan dalam penelitian ini yaitu metode KNearest Neighbor dan Information Gain. Pada tahap pre-processing, dilakukan seleksi fitur dengan menggunakan metode Information Gain sehingga menghasilan new dataset dengan atributatribut yang paling optimal. Kemudian new dataset dibagi dengan metode 10 Fold Cross Validation yaitu data training dan data testing. Kemudian data training diklasifikasi dengan menggunakan metode K-Nearest Neighbor. Langkah terakhir data testing diuji dengan melihat performa akurasi.

\section{K-Nearest Neighbor}

K-Nearest Neighbor merupakan algoritma yang efektif dan kuat. Dalam pengenalan pola, algoritma K-Nearest Neighbor adalah salah satu metode non-parametrik yang paling terkenal dan berguna untuk mengelompokkan objek berdasarkan fitur-fitur yang dekat. K-Nearest Neighbor dirancang dengan konsep bahwa label atau kelas ditentukan oleh suara mayoritas tetangganya (Won Yoon \& Friel, 2015). Prinsip kerja KNN adalah mencari jarak terdekat antara data yang dievaluasi dengan $\mathrm{k}$ tetangga terdekatnya dalam data pelatihan. Persamaan penghitungan untuk mencari Euclidean dengan d adalah jarak dan $\mathrm{p}$ adalah dimensi data dengan:

$\mathrm{d}_{i}=\sqrt{\sum_{\mathrm{i}=1}^{\mathrm{p}}\left(\mathrm{x}_{1 \mathrm{i}}-\mathrm{x}_{2 \mathrm{i}}\right)^{2}}$

di mana:

x1: sample data uji

$\mathrm{x} 2$ : data uji

d: jarak

p: dimensi data

\section{Information Gain}

Information Gain sering digunakan untuk meranking atribut yang paling berpengaruh terhadap kelasnya. Nilai gain dari suatu atribut, diperoleh dari nilai entropi sebelum pemisahan dikurangi dengan nilai entropi setelah pemisahan. Tujuan pengurangan fitur pengukuran nilai informasi diterapkan sebagai tahap sebelum pengolahan awal. Hanya atribut memenuhi kriteria (treshold) yang ditentukan dipertahankan untuk digunakan oleh algoritma klasifikasi (Hand, 2007). Ada 3 tahapan dalam pemilihan fitur menggunakan Information Gain diantaranya adalah:

1. Hitung nilai gain informasi untuk setiap atribut dalam dataset asli.
2. Buang semua atribut yang tidak memenuhi kriteria yang ditentukan.

\section{Dataset direvisi.}

Pengukuran atribut ini dipelopori oleh Cloude Shannon pada teori informasi (Gallager, 2001), dituliskan sebagai (Han, Kamber, \& Pei, 2012):

$\operatorname{Info}(D)=-\sum_{i=1}^{m} p_{i} \log _{2}\left(p_{i}\right)$

di mana:

D: Himpunan Kasus

m: Jumlah partisi D

$\mathrm{p}_{\mathrm{i}}$ : Proporsi dari $\mathrm{D}_{\mathrm{i}}$ terhadap $\mathrm{D}$.

Dalam hal ini $p_{i}$ adalah probabilitas sebuah tuple pada $D$ masuk ke kelas $C_{i}$ dan diestimasi dengan । $C_{i}, D|/| D \mid$. Fungsi log diambil berbasis 2 karena informasi dikodekan berbasis bit. Selanjutnya nilai entropi setelah pemisahan dengan cara sebagai berikut (Han et al., 2012).

$\operatorname{Info}_{A}(D)=-\sum_{j=1}^{v} \frac{\left|D_{j}\right|}{|D|} \times \operatorname{Info}\left(D_{j}\right) \ldots \ldots \ldots \ldots$

di mana:

D: himpunan kasus

A: atribut

$v$ : jumlah partisi atribut $\mathrm{A}$

$\left|D_{j}\right|$ : jumlah kasus pada partisi ke $\mathrm{j}$

$|D|$ : jumlah kasus dalam D

$\operatorname{Info}\left(D_{j}\right)$ : total entropi dalam partisi

Untuk mencari nilai information gain atribut $\mathrm{A}$ diperoleh dengan persamaan berikut (Han et al., 2012):

$\operatorname{Gain}(A)=\operatorname{Info}(D)-\operatorname{Info}_{A}(D)$

di mana:

Gain(A): Information atribut A

Info(D): Total entropi

Info $_{A}(D)$ : Entropi A

Dengan penjelasan lain, Gain (A) adalah reduksi yang diharapkan di dalam entropi yang disebabkan oleh pengenalan nilai atribut dari A. Atribut yang memiliki nilai Information Gain terbesar dipilih sebagai uji atribut untuk himpunan S. Selanjutnya suatu simpul dibuat dan diberi label dengan label atribut tersebut, dan cabang-cabang dibuat untuk masing masing nilai dari atribut

\section{HASIL DAN PEMBAHASAN}

Tabel 3 merupakan perbandingan akurasi metode K-Nearest Neighbor dengan KNearest Neighbor dan Information Gain pada 
klasifikasi kinerja siswa dengan menggunakan dataset student performance. Pada Tabel 3 menunjukkan dengan metode K-Nearest Neighbor didapatkan rata-rata akurasi terbesar yaitu 74,068 sedangkan dengan metode K-Nearest Neighbor dan Information Gain didapatkan rata-rata akurasi terbesar yaitu 76,553. Pada Gambar 2 juga menunjukkan kenaikan grafik pada penggunaan metode K-Nearest Neighbor dan Information Gain dibanding dengan metode K-Nearest Neighbor saja.

Tabel 3. Perbandingan Akurasi K-Nearest Neighbor dengan K-Nearest Neighbor dan Information Gain

\begin{tabular}{lll}
\hline $\begin{array}{l}\text { Percobaan } \\
\text { (k) }\end{array}$ & $\begin{array}{l}\text { K-Nearest } \\
\text { Neighbor }\end{array}$ & $\begin{array}{l}\text { K-Nearest } \\
\text { Neighbor } \\
\text { dan } \\
\text { Information } \\
\text { Gain }\end{array}$ \\
\hline 1 & 68,96 & 72,98 \\
\hline 2 & 62,55 & 67,53 \\
\hline 3 & 75 & 76,24 \\
\hline 4 & 72,6 & 74,52 \\
\hline 5 & 76,34 & 77,78 \\
\hline 6 & 76,34 & 78,07 \\
\hline 7 & 77,58 & 78,84 \\
\hline 8 & 77,11 & 78,93 \\
\hline 9 & 77,1 & 80,56 \\
\hline 10 & 77,1 & 80,08 \\
\hline Rata-rata & 74,068 & 76,553 \\
\hline Sumber: (Setiyorini \& Asmono, 2019)
\end{tabular}

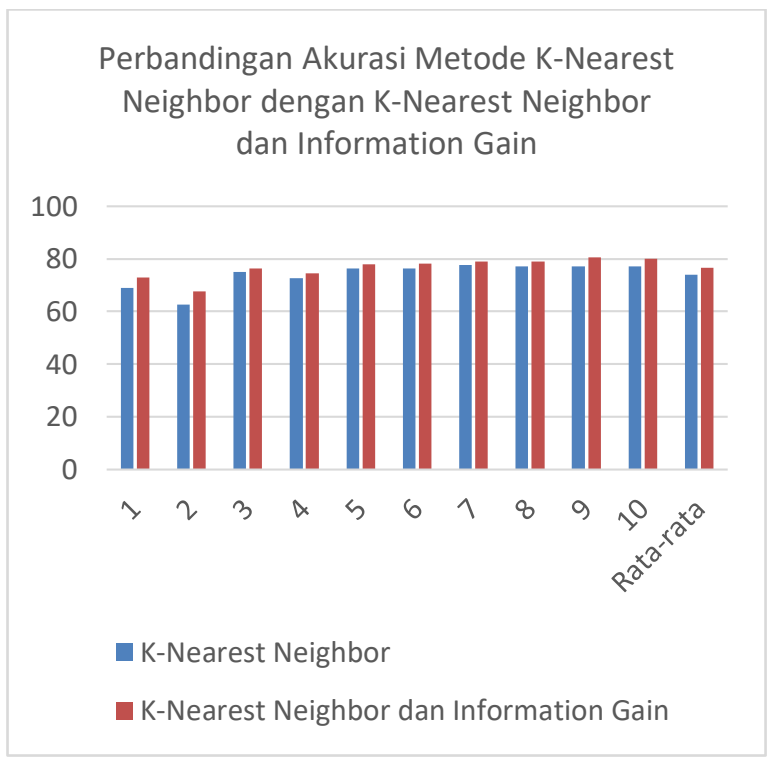

Sumber: (Setiyorini \& Asmono, 2019)

Gambar 2. Grafik Perbandingan Akurasi K-Nearest Neighbor dengan K-Nearest Neighbor dan Information Gain
Dari hasil pengujian tersebut menunjukkan bahwa Information Gain pada KNearest Neighbor mampu mengurangi dimensi vektor, sehingga menghasilkan tingkat akurasi klasifikasi kinerja siswa lebih baik dibanding dengan menggunakan metode K-Nearest Neighbor saja. Hal ini membuktikan penelitan Gorman (George Gorman, 2003), Tan dan Zang(Zhang \& Tan, 2008) bahwa Information Gain mampu mengurangi dimensi vektor. Selain itu hasil tersebut juga membuktikan penelitan Setiyorini dan Asmono (Setiyorini, 2017), bahwa klasifikasi tingkat kognitif soal pada taksonomi Bloom dengan menggunakan metode K-Nearest Neighbor dan Information Gain menghasilkan tingkat akurasi yang lebih baik dibanding menggunakan metode K-Nearest Neighbor saja.

\section{KESIMPULAN}

Hasil dari 10 percobaan dengan nilai $\mathrm{k}$ (1 sampai dengan 10) pada dataset student performance dengan metode K-Nearest Neighbor didapatkan rata-rata akurasi terbesar yaitu 74,068 sedangkan dengan metode K-Nearest Neighbor dan Information Gain didapatkan rata-rata akurasi terbesar yaitu 76,553. Dari hasil pengujian tersebut maka dapat disimpulkan bahwa seleksi fitur dengan Information Gain mampu mengurangi dimensi vektor, sehingga penerapan K-Nearest Neighbor dan Information Gain dapat meningkatkan akurasi klasifikasi kinerja siswa yang lebih baik dibanding dengan menggunakan metode K-Nearest Neighbor saja.

\section{REFERENSI}

Adeniyi, D. A., Wei, Z., \& Yongquan, Y. (2016). Automated web usage data mining and recommendation system using K-Nearest Neighbor (KNN) classification method. Applied Computing and Informatics, 12(1), 90-108.

https://doi.org/10.1016/j.aci.2014.10.001

Aghbari, Z. Al. (2005). Array-index: A plug\&search $\mathrm{K}$ nearest neighbors method for highdimensional data. Data and Knowledge Engineering, 52(3), 333-352. https://doi.org/10.1016/j.datak.2004.06.01 5

Al-Shehri, H., Al-Qarni, A., Al-Saati, L., Batoaq, A., Badukhen, H., Alrashed, S., ... Olatunji, S. 0. (2017). Student performance prediction using Support Vector Machine and K-Nearest Neighbor. Canadian Conference on Electrical and Computer Engineering, 17-20. 
https://doi.org/10.1109/CCECE.2017.79468 47

Alkhasawneh, R., \& Hobson, R. (2011). Modeling student retention in science and engineering disciplines using neural networks. In 2011 IEEE Global Engineering Education Conference, EDUCON 2011 (pp. 660-663). https://doi.org/10.1109/EDUCON.2011.577 3209

Conijn, R., Snijders, C., Kleingeld, A., \& Matzat, U. (2017). Predicting student performance from LMS data: A comparison of 17 blended courses using moodle LMS. IEEE Transactions on Learning Technologies, 10(1), 17-29. https://doi.org/10.1109/TLT.2016.2616312

Cortez, P., \& Silva, A. (2008). Using Data Mining to Predict Secondary School Student Performance. In A. Brito and J. Teixeira Eds., Proceedings of 5th FUture BUsiness TEChnology Conference (FUBUTEC 2008), 512.

de Vries, A. P., Mamoulis, N., Nes, N., \& Kersten, M. (2003). Efficient k-NN search on vertically decomposed data (p. 322). https://doi.org/10.1145/564728.564729

Gallager, R. G. (2001). Claude E. Shannon: A retrospective on his life, work, and impact. IEEE Transactions on Information Theory, 47(7), 2681-2695. https://doi.org/10.1109/18.959253

George Gorman. (2003). An extensive empirical study of feature selection metrics for text classification. Journal of Machine Learning Research, 3, 1289-1305.

Gou, J., Zhan, Y., Rao, Y., Shen, X., Wang, X., \& He, W. (2014). Improved pseudo nearest neighbor classification. Knowledge-Based Systems, 70, 361-375. https://doi.org/10.1016/j.knosys.2014.07.0 20

Hamsa, H., Indiradevi, S., \& Kizhakkethottam, J. J. (2016). Student Academic Performance Prediction Model Using Decision Tree and Fuzzy Genetic Algorithm. Procedia Technology, 25, 326-332. https://doi.org/10.1016/j.protcy.2016.08.11 4

Han, J., Kamber, M., \& Pei, J. (2012). Data Mining Concepts and Techniques. Data Mining. https://doi.org/10.1016/b978-0-12381479-1.00001-0

Hand, D. J. (2007). Principles of data mining. Drug Safety, 30(7), 621-622. https://doi.org/10.2165/00002018200730070-00010

Ibrahim, Z., \& Rusli, D. (2007). Predicting Students' Academic Performance: Comparing Artificial Neural Network, Decision tree And Linear Regression. Proceedings of the 21st Annual SAS Malaysia Forum, (September), 1-6. Retrieved from https://www.researchgate.net/profile/Daliel a_Rusli/publication/228894873_Predicting_ Students'AAcademic_Performance_Comparin g_Artificial_Neural_Network_Decision_Tree_a nd_Linear_Regression/links/0deec51bb04e7 6ed93000000.pdf

Koncz, P., \& Paralic, J. (2011). An approach to feature selection for sentiment analysis. In INES 2011 - 15th International Conference on Intelligent Engineering Systems, Proceedings (pp.

357-362). https://doi.org/10.1109/INES.2011.595477 3

Lin, Y., Li, J., Lin, M., \& Chen, J. (2014). A new nearest neighbor classifier via fusing neighborhood information. Neurocomputing, 143, 164-169. https://doi.org/10.1016/j.neucom.2014.06.0 09

Lopez Guarin, C. E., Guzman, E. L., \& Gonzalez, F. A. (2015). A Model to Predict Low Academic Performance at a Specific Enrollment Using Data Mining. Revista Iberoamericana de Tecnologias Del Aprendizaje, 10(3), 119-125. https://doi.org/10.1109/RITA.2015.245263 2

Lu, L. R., \& Fa, H. Y. (2004). A Density-Based Method for Reducing the Amount of Training Data in kNN Text Classification [J]. Journal of Computer Research and Development, 4, 003.

Pandey, M., \& Taruna, S. (2016). Towards the integration of multiple classifier pertaining to the Student's performance prediction. Perspectives in Science, 8, 364-366. https://doi.org/10.1016/j.pisc.2016.04.076

Setiyorini, T. (2017). Penerapan Information Gain pada K-Nearest Neighbor untuk Klasifikasi 
Tingkat Kognitif Soal pada Taksonomi Bloom. Sistem Informasi STMIK Antar Bangsa, VI, 5762.

Setiyorini, T., \& Asmono, R. T. (2019). Laporan Akhir Penelitian Mandiri (Vol. 1).

Shahiri, A. M., Husain, W., \& Rashid, N. A. (2015). A Review on Predicting Student's Performance Using Data Mining Techniques. Procedia Computer Science, 72, 414-422. https://doi.org/10.1016/j.procs.2015.12.157

Vercellis, C. (2009). Data mining and optomization for decision making. Business Intelligence (Vol.

1). https://doi.org/10.1017/CB097811074153 24.004

Wang, S., Li, D., Song, X., Wei, Y., \& Li, H. (2011). A feature selection method based on improved fisher's discriminant ratio for text sentiment classification. Expert Systems with Applications, 38(7), 8696-8702. https://doi.org/10.1016/j.eswa.2011.01.077

Won Yoon, J., \& Friel, N. (2015). Efficient model selection for probabilistic $\mathrm{K}$ nearest neighbour classification. Neurocomputing, 149(PB), 1098-1108. https://doi.org/10.1016/j.neucom.2014.07.0 23
Xu, T., Peng, Q., \& Cheng, Y. (2012). Identifying the semantic orientation of terms using S-HAL for sentiment analysis. Knowledge-Based Systems, 35, 279-289. https://doi.org/10.1016/j.knosys.2012.04.0 11

Yang, F., \& Li, F. W. B. (2018). Study on student performance estimation, student progress analysis, and student potential prediction based on data mining. Computers and Education, 123(October 2017), 97-108. https://doi.org/10.1016/j.compedu.2018.04. 006

Zhang, J., \& Tan, S. (2008). An empirical study of sentiment analysis for chinese documents. EXPERT SYSTEMS WITH APPLICATIONS, 34(4), 2622-2629. https://doi.org/10.1016/j.eswa.2007.05.028 